\title{
Energetic and Economics of Different Tillage Methods and Conservation Farming in Finger Millet
}

\author{
Ashwani Kumar Thakur* and Sudha Sidar
}

\author{
S. G. College of Agriculture and Research Station, Jagdalpur, Chhattisgarh, India \\ *Corresponding author
}

\section{A B S T R A C T}

\begin{abstract}
Keywords
Tillage, Energetic,

Economics,

Conservation

farming, Finger

millet.

Article Info

Accepted:

28 October 2017

Available Online:

10 December 2017 experimental field was sandy clay loam in texture and available $\mathrm{N}$ was low and, $\mathrm{P}$ and $\mathrm{K}$ were medium. The experiment was laid out in split plot design with two factors namely tillage practices and different conservation farming with three replications. The treatment consisted of three tillage practices viz. $\mathrm{T}_{1^{-}}$Conventional tillage, $\mathrm{T}_{2}$ - Minimum tillage and $\mathrm{T}_{3}$ - Summer ploughing and five conservation farming viz. $\mathrm{C}_{1}$-Opening conservation, $\mathrm{C}_{2^{-}}$ Intercropping with redgram, $\mathrm{C}_{3^{-}}$Mulching, $\mathrm{C}_{4^{-}}$Herbicide application, $\mathrm{C}_{5^{-}}$Combination of all treatments $\left(\mathrm{C}_{1}+\mathrm{C}_{2}+\mathrm{C}_{3}+\mathrm{C}_{4}\right)$. Two crops were taken as a taste crop viz. finger millet $c v$ "GPU 28" and redgram $c v$ "Rajeevlochan". The result revealed that tillage methods produce summer plouging recorded significantly highest gross income, net return, B: C ratio, energy output, energy use efficiency and energy productivity during experimentation. In case of conservation farming, combination of all treatments recorded significantly higher gross income and herbicide application recorded significantly higher net return and B: C ratio among all conservation farming. Energy use efficiency, energy output input ratio, energy intensiveness and energy production were recorded significantly higher in treatment herbicide application and mulching.
\end{abstract}

Investigation was conducted during kharif season of 2016 at Instructional cum Research Farm, S.G. College of Agriculture and research station, Jagdalpur (C.G.). The soil of

\section{Introduction}

Finger millet (Eleusine coracana (L.) Gaertn) is a major food crop of the semi-arid tropics of Asia and Africa and has been an indispensable component of dryland farming systems (Kerr, 2014). Dida et al., (2008) reported that the crop was domesticated in the highlands of Ethiopia and Uganda 5000 years ago, but reached India 3000 years ago. Today, the crop is ranked fourth globally in importance among the millets, after sorghum, pearl millet, and foxtail millet (Gupta et al., 2012). In India, finger millet is primarily grown in the states of Karnataka, Andhra
Pradesh, Odisha, and Tamil Nadu (Dass et al., 2013). Millets are important food for sustaining tribal population in Bastar region of Chhattisgarh. The important small cereals among tribes of Bastar region after rice, kodo millet (Paspalum scrobiculatum L.) and finger millet [Eleusine coracana (L.) Gaertn.] (Verma and Mishra, 2010). The role of tillage in conserving soil moisture and its subsequent beneficial effect on crop productivity has long been recognized Adequate tillage operations controlled weeds and resulted in higher crop productivity, but caused more soil loss and 
were more capital intensive (Dogra et al., 2002). The use of conservation tillage can play an important role in reducing soil erosion and improving soil quality (Uri et al., 1999) and can be an attractive to conventional tillage for farmers because of its potential to minimum labour and fuel consumption and to lower total production cost (Uri, 2000).

\section{Materials and Methods}

\section{Location of the experiment}

The field experiment was carried out during kharif session of 2016 at Instructional cum Research Farm, S.G. College of Agriculture and research station, Jagdalpur (C.G.). Bastar (Chhattisgarh) is situated in between $19^{\circ}$ 05'36.55" North latitude and 81 ${ }^{\circ} 57^{\prime} 34.69$ " East longitude with altitude ranging from 550-760m above mean sea level. The experiment in Kharif season was framed in split plot design with three replications. The main plot treatment consisted of three tillage practices viz. conventional tillage $\left(\mathrm{T}_{1}\right)$, Minimum tillage $\left(\mathrm{T}_{2}\right)$ and Summer ploughing $\left(\mathrm{T}_{3}\right)$ and five Conservation farming viz. opening conservation furrow $\left(\mathrm{C}_{1}\right)$, Intercropping of finger millet + Red gram $\left(\mathrm{C}_{2}\right)$, Mulching with crop residues $\left(\mathrm{C}_{3}\right)$, Weedicide application (Pre emergence): Isoproturon @ $0.5 \mathrm{~kg}$ a.i. ha ${ }^{-1}\left(\mathrm{C}_{4}\right)$ and $\mathrm{C}_{1}+\mathrm{C}_{2}+\mathrm{C}_{3}+\mathrm{C}_{4}\left(\mathrm{C}_{5}\right)$. Net returns were obtained by deducting cost of cultivation from gross returns. The benefit: cost ratio of each treatment was calculated by dividing net returns by cost of cultivation of respective treatments. Energy inputs were calculated and estimated in Mega Joule (MJ) $\mathrm{ha}^{-1}$ with reference to the standard values prescribed by Mittal et al., (1985). These inputs were taken to each treatment of crops. Energy values, which were taken for energy estimation. The standard energy coefficient for seed and straw of crops was multiplied with their respective yields and summed up to obtain the total energy output. The energy input for crops was calculated by adding the respective values of input under these crops. An energy study was done by following formula:

Energy output $\left(10^{-3} \times \mathrm{MJ} \mathrm{ha}^{-1}\right)=$ Total biological yield (Seed + straw) $\mathrm{x}$ Equivalent energy $\mathrm{MJ} \mathrm{kg}^{-1}$

Total produce $(\mathrm{kg})$

Energy use efficiency (kg MJ-1) =

Energy input (MJ x 10-3)

Energy output (MJ ha-1)

Energy output input ratio =

Energy input (MJ ha-1)

Output grain + Byproduct (Kg ha-1)

Energy output input ratio =

Energy input (MJ ha-1)

\section{Results and Discussion}

\section{Economics}

Gross income (Rs ha $\left.{ }^{-1}\right)$, Net return (Rs $\mathrm{ha}^{-1}$ ) and $\mathrm{B}$ : C ratio

The response of various treatments under finger millet on economics parameter i.e. gross income, net return and benefit cost ratio are presented in Table 1 . The data shows that tillage and conservation farming were recorded significantly effect. Treatment $T_{3}$ (Summer plouging) recorded significantly higher net return and $\mathrm{B}$ : $\mathrm{C}$ ratio which was on par with treatment $\mathrm{T}_{2}$ (Minimum tillage). Whereas, in case of conservation farming, treatment $\mathrm{C}_{5} \quad\left(\mathrm{C}_{1}+\mathrm{C}_{2}+\mathrm{C}_{3}+\mathrm{C}_{4}\right)$ recorded significantly higher gross income and treatment $\mathrm{C}_{4}$ (Herbicide application) recorded significantly higher Net return and $\mathrm{B}$ : $\mathrm{C}$ ratio among all the treatment, but it was at par with $\mathrm{C}_{5} \quad\left(\mathrm{C}_{1}+\mathrm{C}_{2}+\mathrm{C}_{3}+\mathrm{C}_{4}\right)$ and $\mathrm{C}_{4}$ (Herbicide application) in net return. Bali et al., (2006) observed that the application of herbicides 
proved most profitable with net returns and benefit: cost ratio. Redgram yield was recorded numerically higher in treatment T3 (Summer ploughing) in different methods, whereas, in case of conservation farming system, treatment $\mathrm{T} 5 \quad\left(\mathrm{C}_{1}+\mathrm{C}_{2}+\mathrm{C}_{3}+\mathrm{C}_{4}\right)$ recorded significantly higher redgram yield among all the treatments. System productivity recorded significant higher in treatment $T_{3}$ (Summer ploughing) followed by treatment T2 (Minimum tillage) and in conservation farming system, treatment $\mathrm{T}_{5}\left(\mathrm{C}_{1}+\mathrm{C}_{2}+\mathrm{C}_{3}+\mathrm{C}_{4}\right)$ recorded significantly highest system productivity during the experimentation.

\section{Energetics}

Energy output, energy use efficiency, energy output input ratio, energy intensiveness and energy productivity have calculated and presented in Table 2. Energy output, energy use efficiency, energy productivity recorded significantly highest in treatment $\mathrm{T}_{3}$ (Summer plouging) but energy output, treatment $T_{2}$ was at par with $\mathrm{T}_{3}$. In conservation farming, energy output recorded significantly highest in treatment $\mathrm{C}_{5}$ among all the treatments.

Energy use efficiency, energy output input ratio, energy intensiveness and energy production were recorded significantly higher in treatment $\mathrm{C}_{4}$ and $\mathrm{C}_{3}$ and it was at par with $\mathrm{C}_{5}$ in energy intensiveness. Borin et al., (1997) noted that the energy use efficiency value increased as the number of soil tillage reduced. In order to compare the tillage methods, the fuel consumption per area was used as a measure for calculating the effectiveness of each method (Yalcin and Cakir, 2006).

Table.1 Economics, Redgram yield and system productivity of finger millet as influenced by different tillage and conservation farming

\begin{tabular}{|c|c|c|c|c|c|}
\hline Treatment & $\begin{array}{l}\text { Gross income } \\
\quad\left(\mathrm{Rs} \mathrm{ha}^{-1}\right)\end{array}$ & $\begin{array}{l}\text { Net Income } \\
\left(\operatorname{Rs~ha}^{-1}\right)\end{array}$ & $\begin{array}{c}\text { B:C } \\
\text { Ratio }\end{array}$ & $\begin{array}{c}\text { Redgram } \\
\text { yield }\left(\mathbf{q} \text { ha }^{-1}\right)\end{array}$ & $\begin{array}{l}\text { System productivity } \\
\left(\mathbf{q} \mathrm{ha}^{-1}\right)\end{array}$ \\
\hline & & \multicolumn{3}{|c|}{ Tillage Methods } & \\
\hline $\mathrm{T} 1$ & 56655 & 35950 & 1.76 & 1.43 & 25.54 \\
\hline $\mathrm{T} 2$ & 47087 & 39634 & 2.11 & 1.62 & 27.70 \\
\hline $\mathrm{T} 3$ & 61927 & 42386 & 2.19 & 2.18 & 29.06 \\
\hline$S E m \pm$ & 782 & 783 & 0.04 & - & 0.47 \\
\hline \multirow[t]{2}{*}{$C D$ at 0.05} & 3154 & 3155 & 0.16 & - & 1.90 \\
\hline & & \multicolumn{3}{|c|}{ Conservation farming } & \\
\hline $\mathrm{C} 1$ & 54292 & 33414 & 1.60 & - & 22.91 \\
\hline $\mathrm{C} 2$ & 49555 & 32318 & 1.88 & 4.33 & 26.91 \\
\hline $\mathrm{C} 3$ & 59757 & 41000 & 2.19 & - & 25.39 \\
\hline $\mathrm{C} 4$ & 62994 & 45187 & 2.55 & - & 27.56 \\
\hline $\mathrm{C} 5$ & 68831 & 44697 & 1.86 & 4.37 & 34.40 \\
\hline SEm \pm & 1444 & 1445 & 0.07 & - & 0.72 \\
\hline CD at 0.05 & 4241 & 4241 & 0.22 & - & 2.12 \\
\hline
\end{tabular}

T1: Conventional tillage, T2: Minimum tillage, T3: Summer ploughing, C1: Open conservation, C2: Intercropping (finger millet + redgram), C3: Mulching, C4: Herbicide application, C5: $\mathrm{C} 1+\mathrm{C} 2+\mathrm{C} 3+\mathrm{C} 4$ 
Table.2 Energy variables as influenced by different tillage and conservation farming

\begin{tabular}{|c|c|c|c|c|c|}
\hline Treatment & $\begin{array}{l}\text { Energy output } \\
\qquad\left(\mathrm{MJ} \mathrm{ha}^{-1}\right)\end{array}$ & $\begin{array}{l}\text { Energy use efficiency } \\
\qquad\left(\mathbf{q} \mathbf{M J}^{-1} \times \mathbf{1 0}^{-3}\right)\end{array}$ & $\begin{array}{c}\text { Energy output } \\
\text { input ratio }\end{array}$ & $\begin{array}{l}\text { Energy productivity } \\
\qquad\left(\mathrm{g} \mathrm{MJ} \mathrm{ha}^{-1}\right)\end{array}$ & $\begin{array}{c}\text { Energy intensiveness } \\
\left(\mathbf{M J} \mathbf{R e}^{-1}\right)\end{array}$ \\
\hline \multicolumn{6}{|c|}{ Tillage Methods } \\
\hline $\mathrm{T} 1$ & 35436 & 64.50 & 2.38 & 161.84 & 6.09 \\
\hline $\mathrm{T} 2$ & 38345 & 80.01 & 3.40 & 231.06 & 6.29 \\
\hline $\mathrm{T} 3$ & 39523 & 99.23 & 3.89 & 264.35 & 6.80 \\
\hline$S E m \pm$ & 653 & 1.29 & 0.04 & 3.26 & 0.11 \\
\hline CD at $5 \%$ & 2632 & 5.21 & 0.24 & 13.14 & 0.42 \\
\hline \multicolumn{6}{|c|}{ Conservation farming } \\
\hline $\mathrm{C} 1$ & 50520 & 87.23 & 4.73 & 322.02 & 8.77 \\
\hline $\mathrm{C} 2$ & 49780 & 68.18 & 4.71 & 320.42 & 8.33 \\
\hline C3 & 55979 & 74.83 & 4.12 & 280.23 & 10.63 \\
\hline $\mathrm{C} 4$ & 60769 & 96.67 & 5.83 & 396.48 & 11.18 \\
\hline C5 & 66213 & 79.32 & 4.76 & 323.98 & 9.06 \\
\hline$S E m \pm$ & 1094 & 2.66 & 0.10 & 6.08 & 0.20 \\
\hline$C D$ at $5 \%$ & 3211 & 7.80 & 0.31 & 17.84 & 0.59 \\
\hline
\end{tabular}


On the basis of one year experimentation on finger millet crop at Bastar Plateu Zone of Chhattisgarh, summer plouging recorded significantly highest gross income, Net return and B: C ratio. Energy output, energy use efficiency, energy productivity recorded significantly highest in summer plouging. In Conservation farming, combination of all treatment recorded significantly higher gross income and herbicide application recorded significantly higher Net return and B: $\mathrm{C}$ ratio among all the treatment.

Energy use efficiency, energy output input ratio, energy intensiveness and energy production were recorded significantly higher in treatment herbicide application and mulching.

\section{Acknowledgement}

The authors are thankful to Project Coordinator, All India Coordinated Research Project on Small Millets (AICRPSM), Bangalore, Karnataka and Dean SG College of Agriculture and Research Station, Jagdalpur, Chhattisgarh for providing grants and physical support for conducting the experiment.

\section{References}

Bali, A. S., Singh, M., Kachroo, D., Sharma, B. C. and Shivran, D. R. 2006. Efficacy of herbicides in transplanted, medium-duration rice (Oryza sativa) under subtropical conditions of Jammu. Ind. J. of Agro. 51 (2): 128-130.

Borin, M. Mi. C. and Sattori, L. 1997. Effects of tillage systems on energy and carbon balance in north-eastern Italy, Soil Till. Res., 40:209226.

Dass, A, Sudhishri, and S. Lenka, N.K. 2013. Integrated nutrient management to improve finger millet productivity and soil conditions in hilly region of Eastern India. J. Crop Improv., 27, 528-546.

Dida, M.M., Wanyera, N., Dunn, M.L.H., Bennetzen, J.L. AND Devos, K.M. 2008 Population structure and diversity in finger millet (Eleusine coracana) germplasm. Trop. Plant Biol., 1, 131-141.

Dogra, P., Joshi B. P. and Sharma, N. K. 2002. Economic analysis of tillage practices for maize cultivation in the Himalayan humid subtropics. Ind. J. Soil conserv., 30(2):172178.

Gupta, N., Gupta, A.K., Gaur, V.S. and Kumar, A. 2012. Relationship of nitrogen use efficiency with the activities of enzymes involved in nitrogen uptake and assimilation of finger millet genotypes grown under different nitrogen inputs. Sci. World J., 1-10.

Kerr, R.B. 2014. Lost and found crops: Agrobiodiversity, indigenous knowledge, and a feminist political ecology of sorghum and finger millet in Northern Malawi. Ann. Assoc. Am. Geogr., 104, 577-593.

Mittal, N. K., Mittal, J. P. and Dhawan, K. C. 1985. Research digest on energy requirement in agriculture sector (1971-82). ICAR/AICRP/ ERAS/ 85 (1): 159-163.

Uri, N. D. 2000. An evaluation of the economic benefits and. costs of conservation tillage. Environmental Geology, 39: 238-248.

Uri, N.D.T., Wood, J.D. and Sanabria, J. 1999. The environmental benefits and costs of conservation tillage Environmental Geology, 38: 111-125.

Verma, P.K. and Mishra, N. 2010. Traditional techniques of processing on minor millets in Bastar district of Chhattisgarh, India. Res. J. Agricultural Science, 1 (4): 465- 467.

Yalcin, H. and E. Cakir, 2006. Tillage effects and energy efficiencies of subsoiling and direct seeding in light soil on yield of second crop corn for silage in western Turkey. Soil and Till. Res., 90: 250-255.

\section{How to cite this article:}

Ashwani Kumar Thakur and Sudha Sidar. 2017. Energetic and Economics of Different Tillage Methods and Conservation Farming in Finger Millet. Int.J.Curr.Microbiol.App.Sci. 6(12): 3665-3669. doi: https://doi.org/10.20546/ijcmas.2017.612.423 